\title{
Learning to Live with Covid-19: MSMEs Perception and Strategies on Business Promotions, Uva region-Sri Lanka
}

\author{
P.I.N. Fernando* \\ Department of Management Sciences, Faculty of Management \\ Uva Wellassa University of Sri Lanka, Sri Lanka, \\ E-mail: imalif@uwu.ac.lk \\ K.W.S.N. Kumari \\ Department of Science and Technology, Faculty of Applied Sciences \\ Uva Wellassa University of Sri Lanka, Sri Lanka, \\ E-mail: sandya@uwu.ac.lk
}

\begin{abstract}
The research is financed by Uva Wellassa University Capital Grant (UWU/RG/019/015)
Abstract

Within the dynamic external environment, the external shocks might create either opportunities or challenges to business. The Pandemic of COVID -19 also an unpredicted, and highly vulnerable, and highly affecting external shock to the business segments. Therefore, this study would focus on the promotional tools and the perception of Micro, Small, and Medium scale Enterprises (MSMEs) during the Pandemic. Data gathered from Uva region MSME's, via interview method, whereas the qualitative analysis-Thematic analysis method has been adopted. The findings highlight four parental themes; (a) Formal marketing Strategies, (b) Informal marketing Strategies, (c) Virtual Marketing Platform, and (d) Patriotic Marketing. As recommendations, strategies for MSME sector have been proposed.
\end{abstract}

Keywords: business promotions, Covid-19 pandemic, marketing, perception, Small and Medium Enterprises

DOI: $10.7176 / \mathrm{EJBM} / 13-10-03$

Publication date:May $31^{\text {st }} 2021$

\section{Introduction}

Sri Lanka is an upper-middle income country with one of the highest per capita income in the South Asian region (World Bank Data Team, 2019) accounted for the majority portion of the population in rural areas mainly engages with small scale business. The importance of the role of commercial banks in the development process continues to be at the forefront of policy debates by encouraging entrepreneurship results for employment generation as well as direct and indirect employment opportunities to a larger crowd that leads to socio-economic development. More generally, economic development accelerating the achievement of wider socio-economic objectives, including poverty alleviation, employment generation, income equality, and foreign exchanges. Commercial Banks play a pivotal role in the economy while providing access to capital in various means. Further, the financial instruments of banks vary from a simple saving account up to investment plans where the ultimate goal is to earn profits. Policymakers have become increasingly interested in understanding the factors associated with the provision of loans to microenterprises in developing countries, primarily because credit access has been recognized as an important tool for small business economic development and poverty reduction (World Bank, 2019). The sector inherits difficulties as inadequate access to capital and finance, inadequate industrial infrastructure, lack of market base information, obsolete technology, lack of modern management skills, and lack of labor training. Customers demand the funds for various reasons as it varies from personal to business or entrepreneurial venturing. The main income generation of the banks is providing funds as loans in return with a considerable interest portion where the focus towards lending is significant.

The meaning of SMEs diverges country to country, region to region, sometimes within one nation. SMEs can be defined as in terms of many parameters such as the number of persons employed, amount of capital invested, amount of turnover or nature of the business, or a combination of the two or more. It is the fact that there is no single or unique definition regarding SMEs (Vijayakumar, 2013). The European Union defines SMEs as the smallscale businesses consist of fewer than 50 employees and the annual turnover is less than EUR 7 million or the annual balance-sheet total must not exceed EUR 5 million while medium scale businesses are considered 50-250 people and annual turnover must be less than EUR 40 million 3 or the annual balance-sheet total must not exceed EUR 27 million.

India defines MSMEs (Micro Small and Medium Enterprises) based on investment in plant and machinery and equipment. The value of the investment depends on the sector as per the MSMED Act 2006 in India. Malaysia defines SMEs based on annual turnover or number of employees since 2013 as per SME Corporation which is a coordinating agency for SME development coming under the Ministry of International Trade \& Industry. Singapore defines SMEs as enterprises having an annual turnover of less than S\$100 $\mathrm{m}$ or less than 200 employees, 
implemented since 2011. Singapore does not define Micro or Small and Medium industries separately but all three types as a whole. After long years without a clear definition for SMEs, the Ministry of Industry and Commerce has finalized a definition for SME in 2015 under its 'National Policy Framework for Small and Medium Enterprise (SME) Development' for SEMs in Sri Lanka. The criteria are annual turnover and the number of employees is given in Table 1 (Wickramatilake, 2018)

Table 1: Definition of MSMEs in Sri Lanka

\begin{tabular}{|l|l|l|l|l|}
\hline \multirow{2}{*}{ Type } & \multicolumn{2}{|l|}{ Annual Turnover (LKR) } & \multicolumn{2}{l|}{ Number of Employees } \\
\cline { 2 - 5 } & Manufacturing & Service & Manufacturing & Service \\
\hline Micro & $15 \mathrm{Mn}$ & $15 \mathrm{Mn}$ & 10 & 10 \\
\hline Small & $16 \mathrm{Mn}-250 \mathrm{Mn}$ & $16 \mathrm{Mn}-250 \mathrm{Mn}$ & $11-50$ & $11-50$ \\
\hline Medium & $251 \mathrm{Mn}-750 \mathrm{Mn}$ & $251 \mathrm{Mn}-750 \mathrm{Mn}$ & $51-300$ & $51-200$ \\
\hline
\end{tabular}

Source : Wickramatilake, 2018

In consonance with the aforesaid definition, employment, assets, and turnover are highlighted. In countries where there are strong MSME sectors, they are as a rule defined by using the number of employees and the size of capital. Of these countries considered, India still uses investment in plant and machinery and equipment as the criteria. Singapore has a less complicated definition based on turnover and number of employees. Sri Lanka's new definition, therefore, is in line with other countries to a greater extent and it is commendable that the Ministry of Industry and Commerce has finally concluded an acceptable definition.

\subsection{Significance of the Study}

The external environment is dynamic, where external shocks of the environment might create either opportunities or challenges to overcome within the field of business. COVID -19 pandemic is such kind of a situation that was unpredicted, and highly vulnerable, and highly affecting to the business segments. Therefore, the studies catering to the COVID-19 related issues might fill up the vacuum that how a business might succeed during a pandemic. Therefore, to study the dynamic nature of small and medium scale business ventures specially with external environmental shocks might be a new avenue of the research literature. This study might have catered to cover promotional tools and the perception of Micro, small and medium scale enterprises (MSMEs) during the pandemic. This study will generate novel pathways on promotional tools, business, and marketing strategies in the digital area and distance marketing methods.

Contribution to the field of business could be discovered throughout the research findings, by providing new theoretical knowledge on promotional behavior and entrepreneur's perception. Since the pandemic is influencing all parts of the world, the economic downturn is also predicted in the world economy by economists. Therefore, this study catered to the MSME sector within the Uva region as to way-forward the business via promotional tools with the pandemic, at the stage of the "NEW NORMAL".

Therefore, the research question has been formulated as:

What kind of perception exists of the Micro, Small and Medium sector enterprises towards the promotions during the COVID-19 pandemic and study their demographic profile?

The research objective has been developed in line with research questions.

To identify the perception of the Micro, Small and Medium sector enterprises towards the promotions during the COVID-19 pandemic and study their demographic profile.

\section{Literature Review}

\subsection{Importance of MSMEs in Socio-Economic Development}

The experience of many countries indicates that entrepreneurship which manifests in the form of Micro, Small and Medium Scale Enterprises (MSMEs) can meaningfully contribute to the attainment of the country's economic development objectives. These objectives include output expansion, employment generation, location of industries among regions of a country, income redistribution, promotion of indigenous entrepreneurship and technology, as well as the production of intermediate goods to strengthen, inter, and intra-industrial linkages. These among others, explain the increased interest, which many countries have shown in the promotion of entrepreneurship (Small Scale Enterprises) since the 1970s. Governments have therefore designed programs of assistance to enhance the achievement of these objectives. The growing concern on employment generation in Sri Lanka poses a challenge not only to individuals but also to the government. At the individual level, the establishment of business enterprises particularly Small or Medium Enterprises in their own has been an alternative to lucrative employment (Muktar, 2009, Gulani and Usman, 2018).

It is widely accepted that the role played by MSMEs towards the economic development of any country is of paramount importance. The contribution of MSMEs towards the economy is considered to be a major force behind developed and fast-developing economies and helps countries to achieve sustainable and inclusive growth. Besides, this sector plays a pivotal role, being breeding grounds and nurseries for small enterprises to become big corporates by gradual creation of entrepreneurial skills of nations. MSMEs are generally labour intensive and can be 
established with relatively less capital. Therefore, this sector helps economies to address the major issue of the unemployment problem to a greater extent and fair distribution of wealth.

The figures given in table 2 will help us to compare Sri Lanka's SME sector statistics with three other Asian economies based on fast-developing (India), developed (Singapore), and similar economy in terms of population (Malaysia). It exhibits that number of SME enterprises is above 95\% except for Sri Lanka while Singapore achieves as high as 99\%. This implied that the SME sector in Singapore for example contributes to over 50\% towards GDP and 70\% towards the creation of employment. The relative contributions of four countries are indicated below highlighting unique features of the SME sector contribution towards economic development in Table 2.

Table 2: Comparison of SME statistics - Sri Lanka with three Asian economies

\begin{tabular}{|c|c|c|c|c|}
\hline Country & $\begin{array}{l}\text { Contribution to } \\
\text { GDP }\end{array}$ & $\begin{array}{l}\text { Contribution to } \\
\text { Employment }\end{array}$ & $\begin{array}{l}\text { No of Enterprises as \% } \\
\text { of the total }\end{array}$ & $\begin{array}{l}\text { GDP per capital Dec. } \\
2017 \text { in US } \$\end{array}$ \\
\hline Sri Lanka & $52 \%$ & $45 \%$ & $75 \%$ & 4065 \\
\hline India & $32 \%$ & $40 \%$ & $95 \%$ & 1751 \\
\hline Malaysia & $36 \%$ & $67 \%$ & $97 \%$ & 9817 \\
\hline Singapore & Over $50 \%$ & $70 \%$ & $99 \%$ & 57722 \\
\hline
\end{tabular}

Source: Wickramatilake, 2018

SME sector is considered the core segment of economic development in the country. The country has an SME economy: $70 \%$ of the plantation sector, $85 \%$ of rubber, $100 \%$ of paddy, and $90 \%$ coconut are of smallholdings. Key SMEs in Sector-wise can be identified as; SMEs in the Services Sector: Health Services, Passenger Transport, Freight Transport, Banking and Insurance, Tourism Sector, Telecommunications, Construction, Business Process Outsourcing (BPO), Beauty Care Industry; SMEs in the Plantation and Agriculture Sectors: Paddy Milling, Tea, Rubber, Coconut, Fruits and Vegetables, Minor Crops, Poultry Industry; SMEs in the Manufacturing Sector: Textile and Apparel Industry, Surgical Gauze Industry, Leather and Footwear Industry, Gem and Jewelry Industry, Edible products, including milk/fish-based products, etc.

According to Venkatapathy and Pretheeba (2012), in Sri Lanka, Small and Medium Enterprises are being played a great role. It has been a significant provider of employment. It is estimated that in terms of value, the sector accounts for about 25 percent of the manufacturing output. The sector is estimated to employ about 15 lakh persons in over 20 thousand enterprises throughout the country. Further, this sector has consistently registered a higher growth rate than the rest of the industrial sector. Over 1000 products are ranging from traditional to hightech items (SMEDeF, 2011). It is well known that the Micro, Small, and Medium Enterprises (MSME) provide good opportunities for both poverty alleviation and to reduce the social ills associated with unemployment in the economy. It provides the raw materials needed by the manufacturing sector hence vehicle for industrialization. Its role in the local supply of raw materials has twin positive effects of cost-saving to the manufacturing firms as well as the moderation of the tendency of the balance of payment deficit. Further, Due to low assets base, bank demand for collateral denies most SMEs access to capital. Kanak and Iiguni (2007) explain that the poor who often engage in SMEs produce at subsistence level have difficulty to increase their savings or assets that could guarantee access to credit from formal finance. According to Dirk and David (2008), states that microfinance is a multifaceted benefactor that affords them the means to rebuild livelihood, plan for client future and that of their children, empower women with self-esteem, integrate into social fabric by enjoying access to social networks and making contributions towards the welfare of their families and that of the community (Venkatapathy and Pretheeba, 2012).

SMEs effects can be seen in several areas, as providing job opportunities for the workers, distributing income, alleviating poverty, providing a training ground for the development and upgrading entrepreneurship skills, and serving as important vehicles for promoting forward and backward linkages in geographically diverse sectors of the economy in many countries. SMEs are also a key source of economic growth, dynamism, and flexibility and can adapt quickly to changing market demand and supply situations. They also help to diversify economic activity and make a significant contribution to exports and trade. Similarly, there are some objects to start an SME by a citizen, some entrepreneurs start businesses to become their boss, innovate, self-satisfaction, etc. Therefore, each firm or organization seeks some kind of growth for their survival in the business (Huovinen \& Pasanen, 2010). If there is certain importance of SMEs to the country, several problems have presented as limitations to most of the business which not only affects the growth of the enterprises but also survival susceptible. Among these numerous limitations are the problems of ready access to capital, lack of managerial expertise, poor or absence of infrastructural facilities-especially power to support smooth, effective, and efficient operations (Muktar, 2009). For that reason, it is inappropriately affected by SMEs to conclude the enterprises.

\subsection{Promotional tools within the MSME sector}

Marketing is both an art and a science (Barros et al., 2011), and the fundamental purpose is to link the organization with the customer/market. Hence, the promotion might be the most effective marketing mix element, where to link the business with the market. The main objective of promotion is to identify the target group, decide on best and 
most effective advertising strategies, planning of sales support and public relations, and decide on the best control and monitoring methods and assessing the operation (Santos et al., 2013). According to Mill and Morrison (2009), the buying process of the customer has been categorized into three as; (a) informative promotions - effective at the early stages of the buying process: attention and comprehension, (b) persuasive promotions - effective at the intermediate stage of the buying process: attitude, intention, and purchase, and (c) after consuming the services: reminder promotions. Five promotional tools might work with SME; Advertising, Sales Promotion, Public relations, Personal selling, and Direct marketing (Kotler, 2012). (Astleitner and Keller, 1995) has introduced a different category of promotional types as, events and experiences, that allow us to engage sponsored activities and programs designed to create daily or special brand-related interactions. Further, the second type is interactive marketing related to on-line activities and programs designed to engage customers or prospects, and directly or indirectly raise awareness, improve the image or elicit sales of products and services. Scholar (Astleitner and Keller, 1995) finally introduced the third category, the Word of Mouth (WOM) marketing. The WOM is an important marketing tool, where the oral, written, or electronic communications between people might act as the promotion itself, either positively or negatively.

Scholars have investigated the relationship between promotions, specially monetary promotions, as a suboptimal consequence of price competition caused by myopic management (Buzzell et al.). These critics argue that, in the short run, the proliferation of monetary promotions erodes their capacity to "rent" market share, which explains the reason of unprofitable outcomes (Abraham and Lodish, 1990), (Kahn and McAlister, 1997). Despite its importance, within the long run of an SME, sales promotions might cause for price sensitivity and ultimately destroy the brand equity, with retailers and consumers (Mela, Gupta, and Lehman, 1997). Therefore the tendency towards more cost-efficient promotions that rely less on price is highlighted by scholars (Promotion Marketing Association of America 1994),(Kahn and McAlister, 1997), (Lal and Rao, 1997). Entrepreneurship has a direct link with the leadership of a firm (Colbert, 2003), and motivations are higher with different environmental challenges. Consumer-focused marketing strategies might work well but acts as a challenge for SMEs (Berthon et al., 2008); (Carson, 1990); (O'Dwyer et al., 2009). (Schindehutte et al., 2008). In most scenarios, SMEs personally engaged in promoting novel products/services in relating to clients and partners through rapid and effective communication processes and instruments such as word of mouth (WOM) and personal networking (Stokes, 2000a). However, Stokes et al. (1997) stated that the low priority by the SME's towards marketing as compared with large scale enterprises. Marketing activities tend to strengthen the credibility of the proposition of the business, by linking the history (Martens et al., 2007). COVID-19 pandemic is a sudden shock to all economies of the world, specially both large scale and MSME sector. Further, the adverse situation started in late 2019 and came to the peak within the year 2020, and continuing to the present date, by affecting to the lifestyle of human, by making most of the countries in locked-down situations. As a result, the MSME sector was highly affected, and affecting to-date, due to the limitation of human movement and fear of spreading the disease. Further, large number of restrictions enforced to business sector while creating limitations on social distancing.

Thus, the conceptual model has been developed to investigate to identify the perception towards the business promotions by the MSMEs during the pandemic.

Figure 1: Conceptual model developed by reviewing the literature

External environmental shocks : COVID-19 Pandemic
MSME's Perception towards the promotions
MSME's Streagy development for "New Normal"

Source: Literature review

\section{Research method}

The study population consisted of all the SME sector ventures operating in Uva Region, Sri Lanka, and it consists two districts called Badulla and Monaragala. Stratified sampling method was applied to decide the district sample strata size based on the MSME's registered with Small Enterprises Authority in Uva region and a purposive sampling method was adopted to select 40 MSME's from both districts. Data were collected by conducting telephone interviews and observations during the COVID-19 pandemic, starting from March 2020. During the pandemic, the majority of the respondents express their views on business promotions and future promotional plans, and the majority of MSME's perceived the importance of sustaining the business with the environmental shocks. Data has been gathered of all 40 respondents quantitatively and qualitatively. Also, positive responses received to the study topic. Data analysis was conducted through the qualitative analysis method by adopting thematic analysis. Frequency statistics for categorical data and chi-squared test was applied to find association among categorical data.

Chi-squared test statistics and respective alternative hypothesis can be defined as follows. 


\subsection{Hypothesis}

Hypothesis of the given variable can be defined as following equation.

$$
H_{1} \text { : There is a significant different within the considered categorical variable? ? }
$$

\subsection{Chi-square test statistics}

For a $I X J$ contingency table large sample statistic is,

$$
\chi^{2}=\sum_{i=0}^{n} \sum_{j=0}^{n} \frac{\left(n_{i j}-E_{i j}\right)^{2}}{E_{i j}} \sim \chi_{(I-1) J-1)}^{2}
$$

where $i$ and $\mathrm{j}$ index the rows and columns of the table

$n_{i j}=$ Observed cell frequency, $E_{i j}=$ Expected cell frequency and $N=$ Total number of observations Expected cell frequency is calculated as follows.

$$
E_{i j}=(\text { Row? ? Total } * \text { Column? ? Total }) a ? ? N
$$

\section{Results and Discussions}

This study had to request for demographic information on farmers and data from respondents as presented in Table 3 below and these data are analyzed using chi-squared test to realize the association with variable. Mainly,

\begin{tabular}{|c|c|c|c|}
\hline Description & Categories & Percentages & Chi-square test value (P-value) \\
\hline \multirow[t]{2}{*}{ Gender } & Male & 73.0 & \multirow[t]{2}{*}{$21.1(0.000)^{*}$} \\
\hline & Female & 27.0 & \\
\hline \multirow[t]{3}{*}{ Age Group } & $<35$ years & 28.0 & \multirow[t]{3}{*}{$1.52(0.468)$} \\
\hline & $36-50$ years & 38.0 & \\
\hline & 51 and above years & 34.0 & \\
\hline \multirow{4}{*}{$\begin{array}{l}\text { Education } \\
\text { Level }\end{array}$} & Up to Grade 8 & 25.0 & \multirow[t]{4}{*}{$19.52(0.000)^{*}$} \\
\hline & Up to OL & 35.0 & \\
\hline & Up to $\mathrm{AL}$ & 33.0 & \\
\hline & Diploma/ degree & 7.0 & \\
\hline \multirow[t]{2}{*}{ Marital Status } & Married & 45.6 & \multirow[t]{2}{*}{$0.774(0.379)$} \\
\hline & Unmarried & 54.4 & \\
\hline \multirow{4}{*}{$\begin{array}{lr}\text { Family } & \text { Income } \\
\text { (per } & \text { month } \\
\text { LKR) } & \end{array}$} & Below 30,000 & 22.5 & \multirow[t]{4}{*}{$8.702(0.034)^{*}$} \\
\hline & $30,001-45,000$ & 35.6 & \\
\hline & $45,001-60,000$ & 26.7 & \\
\hline & Above 60,000 & 15.2 & \\
\hline \multirow{5}{*}{$\begin{array}{l}\text { Years of } \\
\text { Existence }\end{array}$} & More than 10 years & 41.2 & \multirow[t]{5}{*}{$34.432(0.000)^{*}$} \\
\hline & $8-10$ years & 21.5 & \\
\hline & $5-7.9$ years & 15.5 & \\
\hline & $2-4.9$ years & 13.1 & \\
\hline & Less than 2 years & 8.7 & \\
\hline
\end{tabular}
collected data were analyzed through thematic analysis, one of the qualitative analysis methods.

Table 3: Frequency statistics of Categorical variables and Chi-squared independent test for variables

Source: Primary data

*Indicates the $5 \%$ level of significant

The results of the table 3 depicts that majority of them are male and their percentage is 73.3 .38 percent of the respondents belong to the age group between 36-50 years, more than half ( 54.4 percent) of them are unmarried. Most of them are not well educated and 60 percent of the respondents have completed educated up to Ordinary level. Monthly family income of the most of the MSME's are low and more than 60 percent average income is below 45,000 LKR. Even though, this study established that most (42.2\%) of the businesses had been in existence for more than 10 years followed by those in existence for $8-10$ years at $20.5 \%$.

Based on the results of the chi-squared test indicated that gender, education level, monthly family income and years of existence of the business are significant at the $5 \%$ level of significant while age group and marital status are not significant.

In addition to the demographic factor analysis, based on the data, the following themes were identified.

\subsection{Parent Theme 1: Formal marketing Strategies}

The majority of the respondents explained the importance of formal promotions during the pandemic as such as advertising, sales promotions, and public relations. The majority of them explained the customer attitude shift towards healthy products, where a large number of customers concern healthy products and immune-boosting food items. Further, sales promotions were highlighted as the best strategy to win the heart of customers, where 
advertising through social media and virtual advertising was highlighted. The following are the highlighted statements by SME's,

"I had trust about the advertisements and TV advertisement was my method of promotion" Respondent 11, Interview, 2020

"Pandemic was a good lesson for us, we lost the majority of our customers due to curfew. Therefore, I believed with sales promotions and direct marketing rather spending on advertising” Respondent 08, Interview, 2020

"younger generation spend most of the time with internet, so I felt better to have a face-book page and try on direct marketing” Respondent 27, Interview, 2020

"I created a Facebook page for my business because I know it will be benefitted to me in this pandemic." Respondent 24, Interview, 2020

\subsection{Parent Theme 2: Informal marketing Strategies}

A lesser number of respondents highlighted the absence of formal marketing strategies and the importance of informal methods during "NEW NORMAL". Therefore, some statements from transcripts to certify their usage of informal promotional strategies.

"I gave the freedom to selecting the product by applying sanitary requirements." Respondent 04, Interview, 2020

"I trust my customers will stay with me if I do believe with informal strategies such as asking whether they are safe at home, deliver goods to their door-steps, and reducing my prices." Respondent 13, Interview, 2020

"We went to our customers' places and hope to continue this further during the pandemic. What we feel the traditional marketing methods might not work now and people are panic. Therefore, we got transportation facilities to reach them", Respondent 28, Interview, 2020

\subsection{Parent Theme 3: Virtual Marketing Platform}

The majority of the respondents highlighted the importance of virtual marketing space. During the pandemic, the majority of MSMEs created or upgraded the virtual marketing opportunities and believe it as a sustainable strategy. Further virtual marketing was highly concerned by apparel sector SME's due to a sudden decrease in customer movements and less demand. Some MSMEs were positive on virtual marketing to reduce the costs of logistics and storage, as well as with promised sales. Some statements herewith presented to highlight the respondent's perceptions.

"We understood why we need a virtual market with this pandemic. I got positive customer feedback to my virtual marketing platform”, Respondent 06, Interview, 2020

"Spending on the virtual market to my business is the best strategy ever, my business sustained due to the strategy. Now I'm getting few orders with a significant monetary value per day from the virtual customers." Respondent 11, Interview, 2020

"Our business created its Facebook page and virtual marketing platform during the pandemic. We understood why it important during this digital era, and now we believe we can better face the challenge", Respondent 14, Interview, 2020

\subsection{Parent Theme 4: Patriotic Marketing}

Some of the respondents highlighted the importance of patriotic marketing, the concept of consuming locally manufacturing products, during the pandemic. The majority of MSMEs related to the Food and Beverages industry highlighted the concept and stated the perception as a promotional tool. Statements related to the concept have been presented to highlight the respondent perceptions.

"We observed the tendency of our customers towards the locally manufactured products during the period. In future we will focus our product range more on local produce", Respondent 06, Interview, 2020

"I always feel, as Sri Lankan people we must prioritize our consumption to local food products. Then we can reduce what we importing from other countries" Respondent 05, Interview, 2020

"During the pandemic, I got many orders to locally manufactured handloom products, and I observed my customers changed their attitude on imported products, even with low price” Respondent 26, Interview, 2020

\section{Discussion}

Any organization success purely depends on its employees and quality of the works they have done. Based on the perception of MSMEs, the majority of enterprises were in an unfavorable situation due to the COVID-19 pandemic. This was observed not in the Uva region only, as common to all Enterprises in both the MSME sector and largescale businesses. As the discussion, the majority of respondents highlight the importance of formal marketing strategies by linking with the virtual market with the internet and social media might work well with the pandemic. Further, direct marketing tools are also practiced by some MSMEs and stated the importance of "go to the customer while they stay at home". Further, some respondents' highlights the direct marketing might become the most effective method comparing to the advertising and sales promotion, since the MSME can easily reach the customer 
base. Beyond traditional marketing, some MSMEs rely on informal methods as creating a direct link with the customer through telephone and internet and informal methods. Further, patriotic marketing was also highlighted as MSME's perception of the strategy with future business opportunities. Respondents perceive this as one of the positive outcomes from the pandemic, where the customer tendency towards locally manufactured products might work well with economic development. Therefore, four parental themes have been developed as the findings from the study in table 4.

Table 4: Results of Thematic analysis

\begin{tabular}{|l|l|}
\hline Parental Theme 1 & Formal marketing Strategies \\
\hline Parental Theme 2 & Informal marketing Strategies \\
\hline Parental Theme 3 & Virtual Marketing Platform \\
\hline Parental Theme 4 & Patriotic Marketing \\
\hline
\end{tabular}

Source: Thematic analysis

\section{Conclusion and Recommendations}

Based on the analysis results of the demographics variables majority of organization owner are male and they are not well educated. Even though they have the low monthly family income, they started their business more than 10 years back.

Most of the entrepreneurs prefer interactive marketing were to specialize in interactions with target markets. Most of the MSMEs are rich with strong personal contact with customers rather than impersonal marketing through mass promotions. Further, MSMEs seek conversational relationships in which they can listen to, and respond to, the voice of the customer, rather than undertake formal market research to understand the market place. The COVID-19 pandemic is a novel experience, an external market shock to the business sector, whereas a large number of enterprises live with the fear of bankruptcy. Therefore, this study would identify the perception of the Micro, Small and Medium sector enterprises towards the promotions during the COVID-19 pandemic, by taking the Uva region as a sample, and proposed subsequent strategies as recommendations.

The following recommendations are highlighted as strategies to adopt during the COVID-19 pandemic to the MSMEs sector;

- Strategy to enhance formal and informal promotional strategies together

- $\quad$ Strategy on highlighting direct marketing by the MSME's

- Strategy on developing virtual marketing platform for every MSME

- Enhance the customer communication-feedback system

- Strategy on promoting patriotic marketing by focusing locally produced products to customers

Therefore, the recommendations would be able to uplift the MSME's from economic downturn due to the COVID-19 Pandemic, whereas adopting novel methods on promotions and marketing.

Further, this study highlights many future research areas, whereas the pandemic caused large number of business firms to shutdown partly or completely, due to social distancing. Whereas, the research areas in business operations, innovations, consumer behavior differences and supply chain management within the Pandemic is proposed.

\section{References}

Abraham, M. M. \& Lodish, L. M. (1990) Getting the most out of advertising and promotion. Harvard Business Review, 68, 50-1, 53, 56

Abu Ikponmwosa Noruwa, Ezike John Emeka (2012). The Role and Sustainability of Microfinance Banks in Reducing Poverty and Development of Entrepreneurship in Urban and Rural Areas in Nigeria, International Journal of Business Administration, Vol 3 (3), DOI: https://doi.org/10.5430/ijba.v3n3p33

Astleitner, H. \& Keller, J. M. (1995). A model for motivationally adaptive computer-assisted instruction. Journal of Research on Computing in Education, 27, 270-280.

Barros, C. P., Botti, L., PeypocH, N., Robinot, E. \& Solonandrasana, B. (2011). Performance of French destinations: Tourism attraction perspectives. Tourism Management, 32, 141-146.

Berthon, P., Ewing, M. T. \& Napoli, J. (2008). Brand management in small to medium-sized enterprises. Journal of Small Business Management, 46, 27-45.

Buzzell, R. D., Quelch, J. A. \& Walter, J. Salmon (1990). The Costly Bargain of Trade Promotion, Harvani, Business Review, (March/April), 141, 49.

Carson, D. (1990). Some exploratory models for assessing small firms' marketing performance (A qualitative approach). European Journal of Marketing, 24, 8-51

Colbert, F. (2003). Entrepreneurship and leadership in marketing the arts. International Journal of Arts Management, 30-39.

David Audretsch; Dirk Dohse and Annekatrin Niebuhr, (2008), Cultural Diversity and Entrepreneurship: A 
Regional Analysis for Germany, No 6945, CEPR Discussion Papers, C.E.P.R. Discussion Papers

Godage M. and Fernando P.I.N., (2019), A qualitative approach to explore the promotional behavior of an Entrepreneur: With special reference to Tourism sector, International Research Conference proceedings, Uva Wellassa University

Kahn, B. E. \& Mcalister, L. (1997). Grocery revolution, Addison-Wesley.

Lal, R. \& Rao, R. (1997). Supermarket competition: The case of everyday low pricing. Marketing science, 16, 6080 .

M. G. Gulani, A. Usman (2018). Financing Small and Medium Scale Enterprises (SMEs): A Challenge for Entrepreneurial Development in Gombe State, Asian Journal of Business and Management Sciences ISSN: 2047-2528, Vol. 2 No. 9, PP:17-23

Martens, M. L., Jennings, J. E. \& Jennings, P. D. (2007). Do the stories they tell get them the money they need? The role of entrepreneurial narratives in resource acquisition. Academy of Management Journal, 50, 11071132.

Muktar, M., (2009). The role of microfinance banks in the promotion and development of entrepreneurship in semi urban and rural areas.

O'dwyer, M., Gilmore, A. \& Carson, D. (2009). Innovative marketing in SMEs. European Journal of Marketing, 43, 46-61

Otero M \& Rhyne, E. (1994). The new world of Microenterprise finance. London: IT Publications. State of microfinance in Nepal, ISBN: 1565490304, 9781565490307

Rathnayake K.M.N.D., Fernando P.I.N. , Fernando A.G.N.K. (2019), Impact of microfinance services on growth of Micro-Small and Medium scale Enterprises, International Research Conference proceedings, Uva Wellassa University

Saharia Kanak and Yoshiaki Iiguni (2007). Microfinance Programs and Social Capital Formation: The Present Scenario in a Rural Village of Bangladesh. The International Journal of Applied Economics and Finance, 1: 97-104., DOI: 10.3923/ijaef.2007.97.104

Sanna Huovinen and Mika Pasanen, (2010), Entrepreneurial and management teams: What makes the difference?, Journal of Management \& Organization 16(3):436-453

Santos, M., Diaz, J., Baldemoro, I., Garcia, E., Malansing, R., Bautista, E. \& Silva, M. (2013). Compliance of selected food establishments in Caloocan city with the Philippine accessibility law (BP 344). Hong Kong Physiotherapy Journal, 31, 53-54.

Schindehutte, M., Morris, M. H. \& Kocak, A. (2008). Understanding market-driving behavior: the role of entrepreneurship. Journal of Small Business Management, 46, 4-26.

Sinnathurai Vijayakumar (2013), The status of small and medium enterprises and promotions for their growth in Sri Lanka, International Journal on Global Business Management and research, 1:2

Stokes, D. (2000). Entrepreneurial marketing: A conceptualization from qualitative research. Qualitative market research: An International Journal, 3, 47-54.

Venkatapathy R. and Pretheeba P., (2012), Entrepreneurial competencies among management graduates: a cross cultural study, Gian jyotie journal, Vol. 2 (3), 135-143

Wickramatilake R.M.D., (2018). Development of SMEs in Sri Lanka: Are we serious about SME classification?, e-paper, Wijeya Newspapers Ltd, 4 July,2018

World Bank Data Team, New country classifications by income level: 2019-2020, |JULY 01, 2019, https://blogs.worldbank.org/opendata/new-country-classifications-income-level-2019-2020 